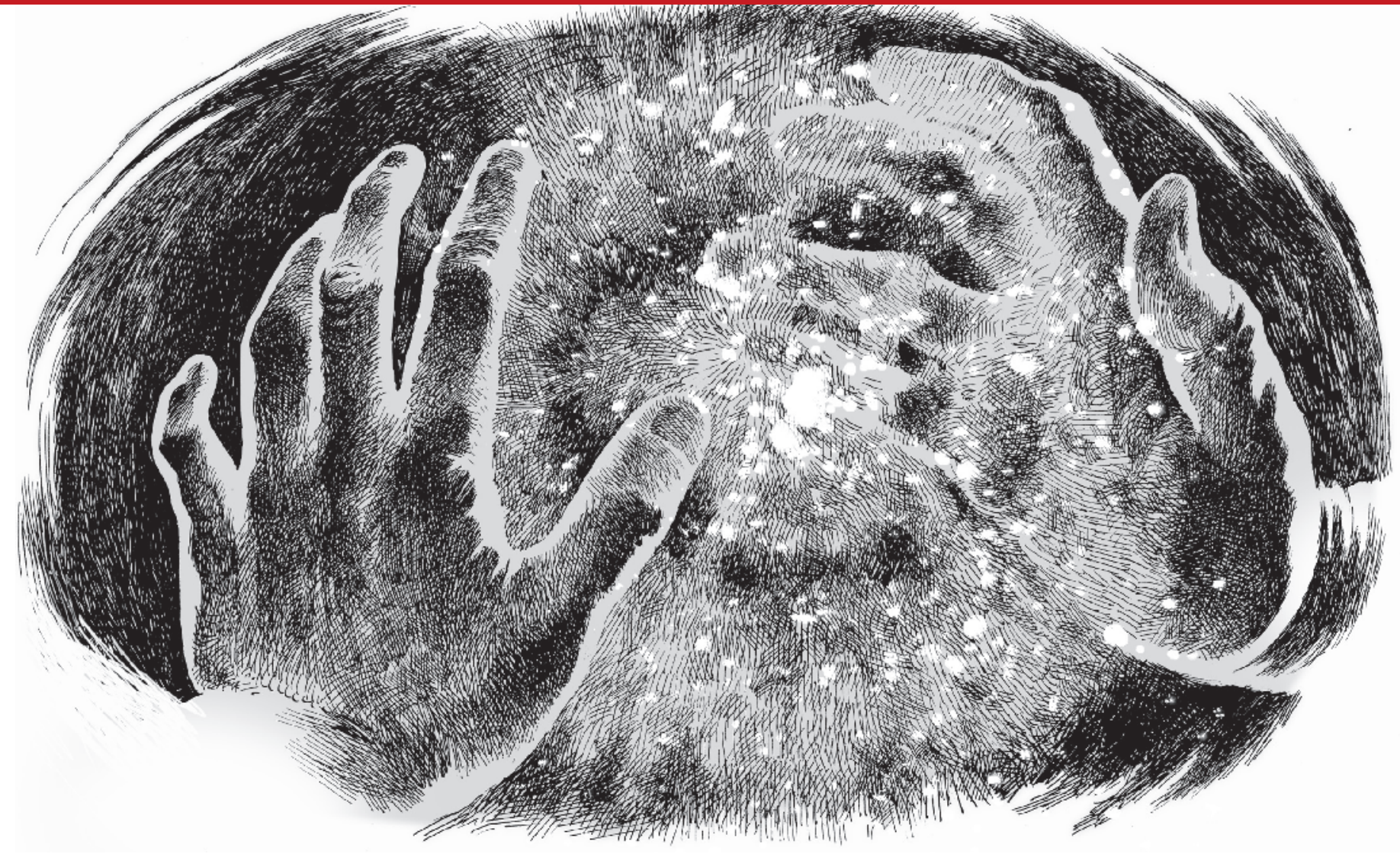

\title{
Welcome to the dark side
}

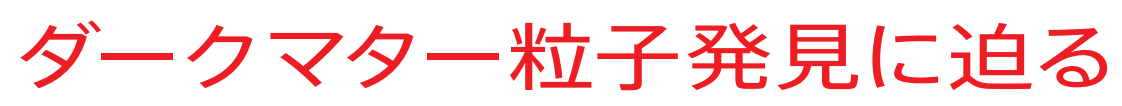

Nature Vol.448 (240-245) / 19 July 2007

物理学者によると、宇宙の 96 パーセントは光で見ることができないという。ダークマター (暗黒物質) とダークエネルギー は、この見えない質量とエネルギーを説明するために考え出された。この記事では、謎に包まれたダークマターの正体を 探る研究が発見の前夜にあることをJenny Hogan が報告する。

私たちは今、イタリア中部の都市ラクイラ の近くにある山の地下 1400 メートルのと ころで、長さ10キロメートルの道路用ト ンネルから分岐した、ほら穴のようなホー ルを歩いている。グランサッソ国立研究 所の地下実験施設の巨大な金属球や塔や 足場の前で働く科学者たちの姿は、アリ のように小さく見える。物理学者Elena Aprileは、自分の研究グループをせき立 てている。1つのプロジェクトに指示を与 えていたかと思うと、次のプロジェクトに 指示を与えている。その途中で、彼女は
$1 つ$ 実験装置の前で立ち止まって写真 を撮り、その大きさに驚きの声を上げた。 やがて私たちは、小さな枝トンネルの奥 におさまったXENON10の実験装置のと ころにやってきた。XENON10 はAprile がここ数年にわたって精力を注ぎ込んで きたプロジェクトであり、ここを通過す るダークマター粒子が姿を現すのを待っ ている。こうした実験装置は、同研究所 のほか、世界にもいくつかある。

かつての新粒子の探索は、粒子が偶 然姿を現すのを待つ方法が主流だった。
1940 年代の科学者たちも山に向かった が、彼らがめざしたのは地下の洞窟では なく頂上だった。彼らは、奇妙な新しい 宇宙線を捕らえるために、乳剂を塗った 乾板を抱えて山を登ったのである。しか し、粒子加速器が強力になり、物理学者 たちが自力で新粒子を作り出せるように なると、偶然の発見を待つ方法は時代遅 れになった。その点では、ダークマター の探索はやや時代に逆行した方法をとっ ているといえる。

ダークマターの探索は、別の点でも昔 
を思い出させる。加速器が強力になれば、 検出器も巨大化し、その出力を分析する のに必要な研究チームの人数も膨れ上が る。スイスのジュネーブ近郊にある欧州原 子核共同研究機関 (CERN) のラージハド ロンコライダー (ハドロン衝突型大加速器、 LHC）の建設には30億ユーロ（約 5000 億円）の費用がかかると見積もられてお り、数千人の科学者とエンジニアが働いて いる。これに対して、XENON10検出器 はわずか 30 人の科学者で動かすことがで き、それが魅力の1つになっている。「こ れは、昔ながらの方法で物理学研究を行う 最後のチャンスなのです」とAprile は話す。 ダークマターの探索においては、小さな 研究チームでも大きな成果を上げること ができる。XENON10は、WIMP（ウイ ンプ、弱い相互作用しかしない質量をもっ た粒子）という種類のダークマターの検出 器であるが、既存の共同研究プロジェクト の検出器の感度を短期間のうちに追い抜 くことができた。ほかの共同研究プロジェ クトも巻き返しをはかっているので、今 後 $2 \sim 5$ 年間は、感度の最高記録が何度 も入れ替わることになりそうだ。サバティ カル (研究休暇) でCERNに滞在してい る英国のシェフィールド大学の理論研究者 Leszek Roszkowski は、「数年前にダー クマター検出器がWIMPを発見したと聞 いたら、私はびっくりしただろう」と話す。 「我々の理解が正しいならば、WIMPは数 年後には見つかっているはずだ。そうで なかったら、私はびっくりするだろう」。

\section{暗黒の巨人}

ダークマターの最初の手がかりが得られ たのは1930年代のことだった。天文学 者のフリッッ・ッビッキーが、かみのけ座 銀河団の中の銀河が奇妙なふるまいをし ていることを発見したのである。銀河の 速度の観測結果は、この銀河団が目に見 える物質の質量よりも大きな質量で結び つけられていることを示唆していた。ツ ビッキーは、「これが確かめられれば、光 を発する物質よりもはるかに大きな密度 をもつダークマターが存在するという驚 くべき結論に達することになる」と書き 記した。
宇宙論研究者たちは現在、ダークマター は、銀河、銀河団、超銀河団、さらには その上の大規模構造まで、すべての宇宙 の構造が形をなすための足場となってい ると考えている。天文学者たちは、ダー クマターの分布地図を作成できる大望遠 鏡を建設中だ。しかし、ダークマターは 星やガス雲や惑星を作っているありふれ た物質ではありえない。ビッグバンの名 残であるマイクロ波放射の詳細な観測は、 そうした通常物質が宇宙のわずか4パー セントにしかならないことを示唆してい る。残りは、通常物質の 5 倍の量のダー クマターと、ダークエネルギーとよばれる 奇妙な反発力であると考えられている。

シカゴ大学 (イリノイ州) の宇宙論研 究者Michael Turnerは、「宇宙の歴史は、 2つの暗黒の巨人の闘いだった」と説明 する。「(宇宙は今から約 137 億年前に誕 生したといわれているが、) 最初の10億 年はダークマターが優勢で、宇宙のすべて の構造を形作った。その後、約 50 億年前 にダークエネルギーが優勢になり、構造の 形成を止め、宇宙の膨張を加速させた」。

1970 年代になると、ダークマターは単 に暗いだけでなく、ほかの物質とは基本 的に異なっているのかもしれないという 考えが支持されるようになった。1980年 代には、Aprileの実験装置のような地下 の検出器の建設計画が始まった。けれど も、この研究分野が熱気を帯びてきたの はつい最近のことである。1つは、WIMP に対する検出器の感度が向上したためで
あり、もう1つは、違った角度からこの 問題に挑戦する実験が行われるように なったためである。

\section{粒子を作り出す}

理論研究者たちがWIMP候補として提案 する粒子のほとんどは質量が大きく、少 なくとも陽子の質量の 100 倍はある。こ れまでの粒子加速器にはここまで重い粒 子を作ることはできなかったが、LHCは おそらくそうした状況を変えることがで き、ダークマター検出器がまだ捕らえら れずにいるものを実験室で作り出せるか もしれない。

LHCの研究者たちが新しい加速器を 使ってこの問題に挑戦している一方で、 天文学者たちは、これとは別のアプロー チから同じ問題に取り組もうとしている。 理論研究者たちが気に入っているWIMP 粒子の中には、互いに相互作用するとき に特徵的なガンマ線バーストやそのほか の奇妙な痕跡を残す可能性があるものも ある。天文学者たちは今、人工衛星や望 遠鏡を使ってそうしたシグナルを探して いるのだ。

地下実験施設でダークマターを捕らえよ うとしている科学者たちは、それでも一 番乗りをめざしている。「今ががんばりど きなのだ。さもないと、間に合わないよ うな気がする」とAprileは話す。過去に CERNで働いたことのある科学者でさえ、 直接探索に注いだ努力に対する報いを得 たいと思っている。現在はカリフォルニア
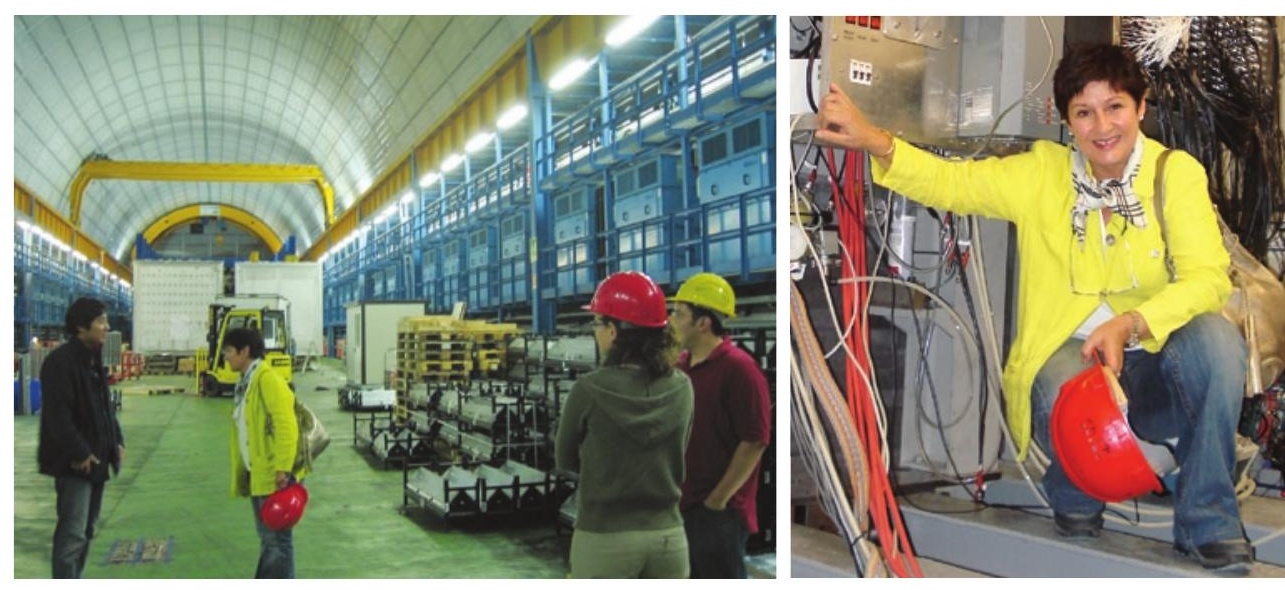

グランサッソ国立研究所（イタリア）のElena Aprile（写真右）は、自分の地下検出器がダークマターを捕 らえるだろうと期待している。 
大学バークレー校でダークマター探索実験 を行っているBernard Sadouletもその 1 人で、「私はダークマターの探索に人生の 20 年を費やしたんだ。最初の目撃者にな りたいと願うのは当然だろう？」と話す。

こうした実験のいずれからも、ダーク マター粒子の証拠が得られる可能性があ る。今までのところ、ダークマター粒子 を直接検出したとする研究結果は1つし かなく、その解釈をめぐる論争が起きて いる(コラム「ダークマターの検出をめぐ る論争」を参照)。だから、宇宙の新しい 構成要素を発見したと科学者たちが自信 をもって主張するためには、複数の方法 から得られた証拠が必要不可欠なのであ る。この粒子が物理法則の新しい枠組み を示すことになる可能性を考えれば、な おさらである。マサチューセッツ工科大 学（同州ケンブリッジ）の物理学者 Max Tegmarkは、「ダークマターの正体につ いてあれこれ思いをめぐらすときほど楽 しいときはない。私たちは本当に発見の 前夜にあると実感している。ダークマター 粒子を発見する方法にはいくつかの種類 があるが、それらのすべてが成功を目前 にしているのだ」と話す。

ダークマターの正体が何であるかはま だ誰も知らないが、それが何でないかは わかっている。物理学の「標準模型」は、
通常の物質とその相互作用についてわ かっていることのすべてを含んでいるが、 ダークマターは標準模型には含まれない。 標準模型は大成功を収めたが、いくつか の問題点もあり、それを解決しようとす る理論研究者たちは多くの新しい基本粒 子を予測してきた。当初は、こうした仮 説的粒子は余計物扱いされていたが、現 在は、そのうちのいくつかがダークマター の筆頭候補になっている。Roszkowski は、「最近では、ダークマター候補をもた ない理論は興味深い理論とは見なされな い。ダークマター問題は、標準模型を超 える物理現象が存在することを示唆する 証拠の中で、最も説得力のあるものとい えるかもしれない」と話す。

標準模型を超える今日の主要な物理理 論の多くは、超対称性理論の仲間である。 超対称性理論では、通常の粒子はそれぞ れ重い超対称性パートナーをもつとされ ているが、これらのパートナーの一部が WIMP候補になっているのである。驚い たことに、ビッグバンから残存している と考えられるそうしたWIMPの数を計算 したところ、ダークマターの宇宙論的観 測值と一致していた。この一致は、ダー クマターが新種の粒子であるという主張 を裏づけるものである。ただし、残存す るWIMPの数の推定值に面食らう人も多
い。典型的なWIMPが陽子の 100 倍の質 量をもつとすると、銀河系内のダークマ ターのモデルからは、地球では 1 平方メ一 トルあたり毎秒約 100 億個のWIMP が通 過していることになる。これだけの数の 粒子が気づかれずに通過していることか ら、通常の物質や光ではWIMPの存在を ほとんど感知できないと考えられる。

このため、WIMPを見つけることは信 じられないほどむずかしい。計算による と、AprileのXENON10検出器を通過す るダークマター粒子は毎週ほぼ1000兆 個に上るが、そのごく一部しか検出でき ないと考えられている。XENON10実験 では、54個の陽子と54個の電子からな る大きなキセノン原子を標的としている。 実験装置を通過するWIMPがごくたまに この標的に衝突すると、少数の光子や電 子としてエネルギーが放出され、感度の 高い装置によって検出されることになる。

ダークマターを直接検出しようとするす べての実験と同様、XENON10検出器は 地下に設置されている。これは、実験結 果に影響を及ぼすおそれのある宇宙線な どの粒子や放射線を途中の岩石に吸収さ せるためである。実験チームにとっての課 題は、バックグラウンドをできるだけ小さ くして、何が残るかを調べることにある。 Aprileは今年になって、XENON10の

\section{ダークマターの検出をめぐる論争}

ダークマターはすでに見つかっ ているのだろうか? イタリア のDAMA共同研究プロジェクト は、自分たちの地下検出器が記 録したイベント数の季節変動は ダークマターのシグナルである と主張している。だが、ほかの 研究者たちは懐疑的だ。彼らの ライバルである米国のCDMSの Bernard Sadouletは、「DAMA の観測結果を、この分野のほか の観測結果と調和させることは ますますむずかしくなってい る」と話す。
銀河系（および銀河系のダー クマター）の静止座標に対する 地球の速度は 1 年の間に変化す るので、地球にぶつかるダーク マター粒子の数も変化すると考 えられる。すなわち、夏には 太陽が銀河系の中心に対して 運動するのと同方向に地球も 運動するので速度は足し合わ されるし、冬にはこの方向が 逆になる。

1995 年から 2002 年にかけ てイタリアのラクイラの近くに あるグランサッソ国立研究所で
行われたDAMA実験は、この 効果を探すためのものだった。 この実験で、100キログラムの ヨウ化ナトリウム標的から成る 検出器は、確かに冬よりも夏に 多くの粒子を検出したため、研 究チームはDAMAがダークマ ターを記録したと結論づけた。

問題は、ダークマターを探 索しているほかの検出器が、 DAMAの結果から予想される 性質の粒子を見いだせないこと にある。この実験を批判する研 究者たちは、季節変動の原因と
なりうるほかの因子（温度や地 下の状態の変化など）の影響を 十分に考慮できていないと指摘 する。DAMAの科学者たちは、 そうした問題は解決ずみである とし、ダークマター粒子は何か もっと風変わりなものに違いな いと主張する。

2008 年末までにDAMA/ LIBRA とよばれる改良型検出 器での観測結果が得られる予 定になっており、この論争を 前に進めると期待されている。

J.H. 


\section{WIMPの探索}

WIMP とよばれるダークマター 粒子を捕らえるための検出器は、 今のところまだWIMPを見つけ ることができずにいる。しかし、 悪い知らせばかりではない。

WIMPの存在を予言する物理 理論を使って、WIMPがどのよ うな性質をもっているかを計算 することができる。このグラフ 中の雲のような形は、WIMP候 補として人気のあるニュートラ リーノがもっているはずの性質 を推測してみたものである ${ }^{2}$ 。

このグラフで、各検出器の感 度限界 (グラフを左右に横切 る線）よりも上にある粒子は、 これまでの実験結果から除外
される。それよりも下のすべ ての領域（つまり、理論から 推定される雲状の領域のほと んど）にある粒子は、これか ら見つかる可能性がある。

検出器の感度は、これから数 年以内に雲状の領域の中心部 (赤で図示した部分) に到達す るはずだ。理論計算は、この領 域をニュートラリーノが最もあ りそうな領域と推定している。 一方、ラージハドロンコライダー (LHC) でも ニュートラリーノ を作れるかもしれないが、それ はニュートラリーノの質量が十 分に軽いときに限られる。

J.H.

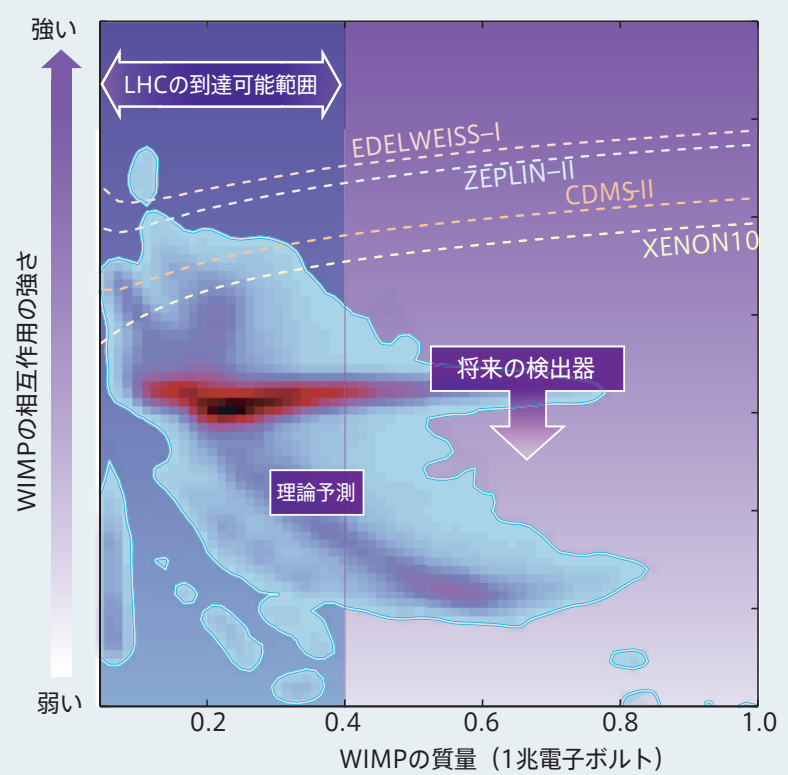

最初の観測結果が得られたと報告した ${ }^{1}$ 。 まだ論文は発表されていないが、その報 告はライバルたちを驚かせた。XENON10 は、これまでで最もよい観測結果を得て いた低温ダークマター探索実験（CDMS） という地下実験とはまったく異なる技術 を使っていたからである。米国ミネソタ 州で行われているCDMSは、極低温に冷 却したゲルマニウムとケイ素の結晶の中 で、粒子衝突によって生じる振動と電荷 を探そうとするものである。これに対し てXENON10検出器は、15キログラムの 液体キセノンを満たした容器を使ってダー クマター粒子を捕らえようとするもので ある。Aprileの結果が発表されたことで、 希ガス液体を使った実験は、これまでの 遅れを取り戻したのだ。

XENON10は最初の60日間の運転で、 直ちに捨て去ることができない10個のイ ベントを記録した。「ここで飛び上がって 『私たちは10個のWIMPを見つけた』と 叫ぶ人もいるかもしれないが、もちろん 私たちはそうはしなかった」と彼女は話 す。Aprileの研究チームは、詳細な分析 によりイベントの半数を除外し、残りは
分析をくぐり抜けたバックグラウンドシグ ナルであるとした。研究者たちがWIMP の一端を捕らえたと考えるためには、ほ かの方法では説明できないイベントが少 なくとも15個は必要なのだ。そしてその 場合も、「直接検出したと主張する前に、 バックグラウンドの理解を深めることが必 要なのだ」とAprileは話す。

\section{獲物を追い詰める}

否定的な結果も重要だ。XENON10検出 器の感度の高さは、仮説上の存在である WIMPの性質 (その質量や物質との相互作 用の強さなど）を絞り込むことを可能にす る。こうした情報は、ダークマター粒子の ように謎に包まれたものを探している場合 には極めて重要だ。XENON10は、これ までで最もよい観測結果よりもさらに厳し い絞り込みをかけることができる。すでに その実験結果は、超対称性理論がWIMP の存在を予測している領域に食い込み始 めている (コラム「WIMPの探索」を参照)。

ほかの観測プロジェクトもXENON10 のすぐ後ろに迫っていて、さらに弱い相 互作用しかしない粒子を探している。そ
うした粒子を見つける可能性を高めるた めには、ダークマター検出器の規模を大 きくし、バックグラウンドを減らしていく 必要がある。

キセノンを使った実験にはZeplin3 と いうライバルがいる。Zeplin3の設計者 らは、検出器にさまよい込んでくるシ グナルを最小にするために細心の注意 を払ってきた。この実験の結果は、今 後 $1 、 2$ 年で得られると期待されている。 Zeplinは、1990年代の初めに始まっ た英国の共同研究プロジェクトであり、 Aprileは単独で実験を行うことを決める までこのチームと連絡を取り合っていた。 プロジェクトの代表者であるロンドン大学 インペリアルカレッジのTim Sumnerは、 「私たちがZeplinの設計をすでに終えて いたときにXENON10が参入してきて、 いいところをもって行ってしまった。こ れはいらだたしいことだ。しかし、前向 きに考えるようにすべきだろう。Aprile らの装置は、この技術がうまくいくこと を示したのだから」と話す。

12 キログラムのキセノンを使った最 新の検出器を英国北東部のノースハンプ 
い超対称性パートナーである。なぜなら これは、崩壊して別のものになることが できないからだ。単純なモデルの多くは、 4 種類の粒子の超対称性パートナーの混合 粒子であるニュートラリーノが最も軽く、 ビッグバンから現在まで生き残っている ほど安定していると予言する。その結果、 この奇妙な粒子(これは自分自身の反粒 子でもある) は、素粒子物理学者の間で 最自気のあるWIMP候補になっている。

ニュートラリーノを検出する第3のルー トは、それが崩壊した証拠を探すことであ る。ニュートラリーノはそれ自身の反粒子 であるため、十分に接近すると衝突して対 消滅するはずだ。このような対消滅の結 果、ガンマ線、ニュートリノ、あるいは粒 子と反粒子の対が生まれるかもしれない。

例えば、銀河系のダークマターのモデ ルは、銀河系のダークマターハロー（ダー クマターが分布している領域）や銀河系 の中心部に集中したニュートラリーノの対
消滅からガンマ線の輝きが生じる可能性 を示唆している(左ページの図を参照)。 2008年の初頭に打ち上げられる予定のガ ンマ線広域宇宙望遠鏡（GLAST）などの 人工衛星は、これを見つけることができ るかもしれない。さらに、ニュートリノ望 遠鏡（南極に建設中のアイスキューブニュー トリノ検出器など）を使った観測から、 太陽の中心部に集まったニュートラリーノ の対消滅が推測できるかもしれない。こ の場合には、ほかのプロセスよりも高エ ネルギーのニュートリノが生成すると考え られているからである。

しかし、ダークマターがニュートラリー ノではなく、WIMPでさえなかった場合 にはどうなるのだろう？ ダークマターの 正体については、超対称性理論やWIMP をまったく必要としない説明も提案され ている。こうした仮説には、重力の法則を 修正することでダークマターを不要とする もの (コラム「重力の法則を変える」を参照)
から、まったく異なる種類の粒子を提案 するものまで、さまざまな種類がある。

ニュートラリーノの主なライバルはアク シオンだ。アクシオンは、標準模型の小さ な問題点を解決するために1977年に素 粒子物理学者によって提案された粒子で ある。多くの理論研究者たちは、アクシ オンは、いつかは見つかるだろうと考え ているが、宇宙論から期待されるとおり の質量と相互作用をもっているかどうか ははっきりしない。アクシオンの質量は すでに、一方は理論から、他方は超新星 の観測から限界を設定されており、典型 的なニュートラリーノの 10 兆分の 1 未満 であると予測されている。

米国カリフォルニア州のローレンスリバ モア国立研究所で行われているアクシオン ダークマター実験は、ダークマター問題に おけるアクシオンの役割につき最終的な 答えを出すことをめざしている。この実 験の共同代表者であるLeslie Rosenberg

\section{重力の法則を変える}

1970 年代の詳細な観測により、 銀河の外側にある星の速度は、 銀河内の「見える質量」の重力 だけでは引き止めておけないほ ど速いことがわかった。ダークマ ターは、これを引き止めるのに必 要な重力を補う方法の1つとして 提案された。しかし、だれもが 新しい種類の物質が必要である と考えているわけではない。一 部の科学者は、観測結果を説明 する1つの方法として修正二ュー トン力学 (MOND) を提案した。 MONDは1981年に初めて 提案された理論であり、長距 離で重力が弱くなるペースが、 ニュートン力学から期待される ペースよりもゆっくりになると するものである。MONDの現 代版には少数の支持者がいる が、この理論では説明しにく い観測結果が多く、支持を広 げるには至らなかった。
昨年夏に、2つの衝突する銀 河団の観測から「ダークマター が存在する直接的な証拠」が得 られたと米航空宇宙局 (NASA) が発表したことで、MONDは さらなる打撃を受けたようだ。 銀河団の周囲で光が曲げられ る「重カレンズ」という現象に 注目することで、ダークマター について調べることができる。 この重カレンズ効果から、銀河 団の質量の分布が銀河団の高 温のガスの分布とは異なって いることがわかったのである。

研究者たちは、「弾丸銀河 団」(右写真) は、1つの銀河 団がもう 1 つの銀河団を引き 裂くように通過したことで形 成されたと結論づけた。その 際、銀河のガスは衝突に巻き 込まれたが、ダークマター粒子 はまっすぐに進んでいったと みられている。

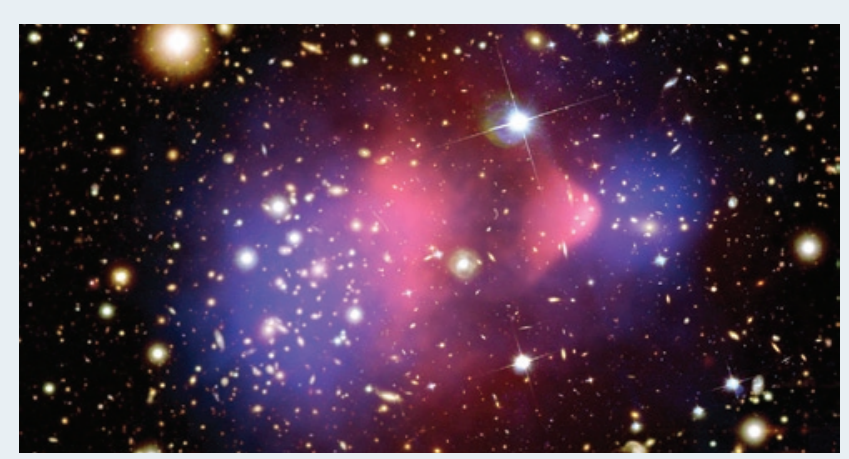

銀河団 1E 0657-56 (別名弾丸銀河団)。ハッブル宇宙望遠鏡が撮影した可視光の 画像にX線天文衛星チャンドラで観測された高温ガスの分布（ピンク）と重カレ ンズで検出されたダークマターも含めた質量の分布 (青) が 重ね合わせられてい る。見える物質 (ピンク) とダークマター（青）の分離が検出され、ダークマター が存在する有力な証拠となった。

MONDの研究者である英 国セントアンドリュース大学の HongSheng Zhao も、NASA の観測結果がある種の「暗い」 粒子の存在を裏づけていること は認めている。しかし彼は、こ れによりMONDが否定された とは考えておらず、観測結果
はMONDと通常のニュートリ ノの組み合わせにより説明でき ると主張する。「代替理論を追 求することは研究として健全な ことだ」とZhaoは話す。彼の 解釈が正しいか否かは、将来の ニュートリノ質量の測定により 検証されることになる。 J.H. 
によると、シアトルのワシントン大学に検 出器を移設した後、2011年までに結果 が得られる予定であるという。アクシオ ンの相互作用は非常に弱いので、粒子加 速器ではめったに生じない。このため実 験では、わずかな粒子エネルギーを検出 できる無線受信機を使ってアクシオンの 兆候を探すことになるという。

アクシオン探索計画の数は、WIMP探 索計画に比べて非常に少ない。これに は、アクシオンを見つけるのに必要な技 術が素粒子物理学者にはあまりなじみ がないものであることが関係している とRosenbergは考えている。さらに彼 は、「超対称性理論はとても人気が高く、 WIMPはその人気に乗っている」と指 摘する。今回紹介したダークマター探索 チームはどれも、ダークマターの正体が自 分たちの予想とはかけ離れたものであっ たとしても、自分たちの研究を続け、何 らかの答えを出したいと決意している。 Aprileは、「ダークマターが予想とはまっ たく違うものであったとしても、それは 受け入れる」と話す。「私はイタリア人女 性でせっかちなの。検出器を改良しなが ら、次のステップをどんどん進めていく だけです」。

しかし、1つの実験が成功したからと いって、ほかの実験が失敗したことにはな らない。科学者たちは単純さを好むので、 WIMPが見つかったらアクシオンはいらな いし、アクシオンが見つかったらWIMPは いらないと考えるかもしれない。けれど も、両方があってもいいのではないか? ダークマター問題は、私たちが考えている よりも豊かな問題であることが分かるか もしれない。Tegmarkは、そうした結果 を期待している。「それはすばらしい番狂 わせだ。自分たちに見えないからといっ て、ダークマターが 1 種類しかないと考え るのは、人間の傲慢というものだ」。

Jenny Hogan はロンドンの Nature 記者。

1. Angle, J. et al. preprint at http://arxiv.org/abs/ 0706.0039(2007).

2. Roszkowski, L., Ruiz de Austri, R. \& Trotta, R. preprint at http://arxiv.org/abs/0705.2012 (2007) 